\title{
I Ungarn spiser de hjerne
}

\author{
Når legene på Rikshospitalet har en faglig nøtt som er vanskelig å knekke kontakter de gjerne Emilia Kerty. \\ Det samme gjør landets nevrologer. - Jeg liker disse nøttene, sier professoren som inntil nylig var Norges \\ eneste spesialist i både øyesykdommer og nevrologi.
}

Emilia Kerty tar imot meg på kontoret sitt på Rikshospitalet og serverer en kopp instant kaffe og en unnskyldning for at hun spiser på et eple. For første gang i hele hennes karriere er lunsjen gjenglemt hjemme. De to brødskivene med salami og tomat, lagt mot hverandre og delt i to på samme måte som i alle år, savner hun sårt akkurat nå. Men eplet får duge. Hun lener seg tilbake i kontorstolen, legger beina i kors og er spent på hva jeg vil spørre om. Kan ikke fatte at hun er interessant.

- Du må love ikke å trykke noe intervju hvis du ser at det blir fryktelig kjedelig.

Med sine brune vakre øyne utstråler hun en mild autoritet - men ikke mildere enn at uklare spørsmål eller slurvefeil i researchen fremkaller rødme og ekte skam hos Tidsskriftets utskremte. Hun er nok en streng sjef. Streng, rettferdig og klok.

- Jeg blir altfor ofte rørt til tårer, men kan også bli veldig sint. Du vet, ungarere har et lynne som gjør at vi gir uttrykk for glede, sorg og sinne i langt sterkere grad enn nordmenn, sier hun.

\section{Champagnekork i øyet}

Skjønt, hun føler seg minst like mye som en nordmann etter snart 37 år i landet. Det var kjærligheten som brakte henne hit. Som øyelege ved universitetssykehuset i Budapest fikk hun en pasient som hadde fătt en champagnekork i øyet. For den norske lutt med penger i lommen på legefrakken såkalt parasolventia. Så da denne pasienten hadde reist hjem fra sykehuset til Norge var kollegene mine så spente på hva jeg hadde fått fra ham. Jeg fikk ikke penger i lommen, men en stor stabel med utenlandske tidsskrifter i favnen, ler hun.

Både hun og mannen Svenn er begge svært beleste, og på Emilias nattbord ligger det alltid en bok. Skjønnlitteratur må det være, gjerne ungarsk, og hun er selvutnevnt ambassadør for moderlandets beste forfattere. Dagens anbefaling er boken Døren av Magda Szabò.

\section{Ingen skippertak}

Emilia vokste opp i Kaposvar, sørvest i Ungarn, og merket lite til utfordringene landet slet med.

- Jeg har aldri følt noe savn eller hatt noen ubehageligheter fra regimets side, selv om jeg vet at både mine foreldre og andre hadde store problemer. Jeg hadde en fin barndom, tok min utdanning og hadde ingen planer om å forlate hjemlandet, sier hun.

Hun er glad for medisinutdanningen hun fikk med seg fra Pécs og Budapest, der mange norske medisinstudenter også årlig uteksamineres.

- Studiet er beinhardt og strukturert. Man tar ikke skippertak før én eksamen, men må prestere på jevnlige småprøver. For å komme inn på studiet må man blant annet

\section{«Jeg var veldig bevisst da jeg søkte professoratet, at hvis jeg får det fordi jeg er kvinne, da tar jeg det ikke imot»}

pasientens vedkommende var det kjærlighet ved første enøyde blikk, og den julen fikk Emilia Kerty det mest gylne julekortet hun noensinne har sett. Nordmannen kom tilbake et halvt år senere og ville takke henne for den gode behandlingen han hadde fått ved å be henne ut på middag. Det endte med ekteskap og nytt hjemland for den unge øyelegen.

- Det morsomste, synes jeg, er at i Ungarn var det vanlig at pasienter som var fornøyd med behandlingen puttet en konvo- igjennom en muntlig og skriftlig opptaksprøve samt en samtale med flere professorer som sjekker egnetheten din. Grunnutdanningen er meget kunnskapsbasert. Samtidig legges det gjennom hele studiet stor vekt på de kliniske trekkene ved sykelige tilstander fremfor avanserte teknologiske metoder.

\section{Fikk opp øynene for nevrologi} Emilia Kerty kom igjennom nåløyet i Ungarn, men i Norge måtte hun igjennom en ny og grundig bevisrunde. Norskkurs, tilleggskurs i kirurgi, distriktsturnus i Nittedal, legevaktjobb og bedriftslegevikarjobb for Nationaltheatret og Norges Røde Kors i tillegg til summa cum laude på papirene og to års erfaring fra universitetsklinikk i Ungarn - det imponerte ikke ved Rikshospitalet. Hun fikk ikke engang svar på søknaden sin. Men hva har man ikke landsmenn for? Kerty oppsøkte den ungarske professor Rajka ved hudavdelingen som sporenstreks ringte til professor Thomassen ved øyeavdelingen. Og dagen etter, på sin sønns ettårsdag, kunne hun begynne som hospitant - med full vakttjeneste. Etter et halvt år fikk hun assistentlegestilling samme sted og var dermed tatt inn i varmen. Men for å bli spesialist i øyesykdommer var det obligatorisk med et halvt års nevrologitjeneste, og dermed var Emilia Kerty solgt.

- Nevrologi fascinerte meg fra første dag. Øyefaget er veldig operativt, og det å være en litt over middels operatør er ikke morsomt. Du bør helst være briljant. Nevrologi var utrolig spennende og må jo være det mest logiske faget innen medisinen, sier hun.

Hun fullførte spesialiseringen hun hadde begynt på, og hoppet så over til nevrologien - et ikke helt ulogisk hopp. Merkelig nok var hun i mange år den eneste i Norge med denne kombinasjonen.

- Svært mange nevrologiske sykdommer gir utslag i øyet - både i øyebevegelsene, synsskarpheten og synsoppfatningen. Øyeeplet er øyelegenes domene, men øyet er en fremskutt del av nervesystemet og vår viktigste sans. Omtrent halvparten av hjernebarken brukes til analyse av synsinntrykk, så koblingen øye/nevrologi er veldig logisk. I mange land - vi skal ikke lenger enn til Sverige - er nevrooftalmologi en subspesialitet. Mange har trodd at nye nevroradiologiske metoder ville ta over for de tradisjonelle synsundersøkelsene, men det er absolutt ikke sikkert. Analysering av øyebevegelser betyr fortsatt mye mer enn f.eks. en MR-undersøkelse. Det er svært mange defekter og forstyrrelser i øyebevegelsene som ikke engang viser seg på de nevroradiologiske undersøkelsene fordi defekten er i funksjonen og ikke i strukturen, forklarer professoren. 


\section{Emilia Kerty}

Født 19. april 1948

- Cand.med. Ungarn 1972

- Spesialist i øyesykdommer 1981

- Spesialist i nevrologi 1986

- Seksjonsoverlege, Nevrologisk avdeling, Rikshospitalet

- Professor i nevrologi, Universitetet i Oslo

\section{Nøtter og kjønnskvotering}

Daglig får hun et par henvendelser fra kolleger over hele landet som trenger råd. I posten får hun $\mathrm{CD}$-er med øyebevegelser $\mathrm{og}$ på e-post får hun andre kompliserte spørsmål. Tidkrevende henvendelser som hun besvarer med glede. - Det er veldig krevende og gjør at man av og til er sterkt stresset, men det er likevel bare hyggelig, sier hun.

Hun setter også stor pris på å drive undervisning, og tidligere studenter fremhever hennes engasjement ved forelesninger.

- Undervisning og veiledning bør få mer anerkjennelse. Jeg tenker ikke bare på stipendiatveiledning, men også på veiledning av unge kolleger. Helse-Norges fremtid er avhengig av at vi gir god utdanning til vordende leger og spesialister og oppmuntrer til å kombinere klinisk praksis med forskning.

Når det gjelder forskning, er ikke Emilia Kerty interessert i å fikle med detaljer i allerede etablert kunnskap. Hun vil være avantgarde, sette dagsorden, initiere. Når forskningsprosjektene tikker og går, kan noen andre overta. Doktorgradsarbeidet hennes gikk ut på å finne ut hvilke konsekvenser det blir for øyet når pasienten får forsnevringer i carotisarteriene. I 1990 var hun den første som tok i bruk botolinumtoksinbehandling mot dystonier, og nå forsøker hun og kollegene å finne ut hvorfor idiopatisk intrakranial hypertensjon oppstår.

\section{Elsker pasienter}

Kerty kan smykke seg med tittelen Norges første kvinnelige professor i nevrologi, men det ble ikke spesielt lagt merke til da det skjedde. Heldigvis, mener hun selv.

- I de siste årene har kjønnsfordelingen blant medisinstudentene klart gått i kvinnenes favør. Kvinnenes karriere blir ofte forsinket, men da må man ta med i betraktningen at vi har andre og meget viktige funksjoner å ta vare på først. Derfor syns jeg kvotering er en uting. Det gjør kvinnens stilling vanskeligere. Kvoterte kvinner må plutselig forsvare kvaliteten de besitter. Jeg var veldig bevisst da jeg søkte professoratet, at hvis jeg får det fordi jeg er kvinne, da tar jeg det ikke imot, sier hun bestemt.

Emilia Kerty er ikke en helt vanlig professor, i den forstand at hun fremdeles jobber mye i klinisk praksis. Hun klarer ikke å la være, selv om det går ut over tiden hun kunne ha brukt til forskning.

- Jeg elsker pasienter. Det er tross alt derfor vi er her. På avdelingen vår har vi mange vanskelige kliniske problemstillinger, mange annenhåndsvurderinger og symptomer som krever en del detektivarbeid. - Du liker disse nøttene?

- Ja, det er disse nøttene som gjør at vår hverdag er så spennende. Det går ikke opp tidsmessig, men legeyrket skal ikke være en produksjonsanstalt, da mister det mye av sin verdi. Det er svært viktig å opprettholde en høy faglig standard. Hvis det eneste vi rangeres etter er kvantitet og ikke kvalitet, da blir alle parter skadelidende. Pasienten får ikke den optimale behandlingen, og legen får ikke den gode følelsen av velutført arbeid. Dette kan raskt føre til slitasje og utbrenthet. Det er viktig å være klar over at dette ikke er en industri, sier hun strengt.

\section{Oppskrift på hjerne}

Etter nærmere 30 år i faget er hun ikke blitt blasert, og lar seg ofte røre til tårer av pasienters skjebne. Altfor ofte, ifølge henne selv. Hun ser på det som en plagsom svakhet og skylder på ungarsk sentimentalisme. Jobben tar hun med seg hjem, både $\mathrm{i}$ hodet og i vesken. Familien har likevel fått henne hjem til middag, som ofte tilbringes med sønnen og hans familie, og så har jobben fortsatt på kvelden. Mannen Svenn er også en opptatt person, som selvstendig næringsdrivende og leder av Klimarealistene. Det sistnevnte er et skjellsord i mange kretser. Klimarealistene tror ikke på eksper- tene i FNs klimapanel og bestrider at klimaforandringene er menneskeskapt.

- Deler du det synet?

$-\mathrm{Nja}$, jeg tror de har mye rett. Jeg tror at mange overvurderer vår makt over klimaet. Den promillen $\mathrm{CO}_{2}$ som menneskene skaper, tror jeg ikke har den enorme virkningen som politikerstyrte organisasjoner prøver å få oss til å tro. Men det er viktig at man skiller mellom klima og miljø. Gasser og gifter er noe helt annet enn klima og $\mathrm{CO}_{2}$.

Professoren og klimarealisten er storforbrukere av kultur. De sluker bøker, har klippekort i operaen og går mye på kino og teater. Emilia spiller dessuten tennis og later som om hun spiller bridge. Bridgeklubben er mer et venninnetreff egentlig. Helgene er rutine: lørdag opera, søndag storproduksjon av middag.

- Søndag lager jeg middag for hele uken. - Imponerende! Det skulle jeg gjerne kopiert.

- Ikke gjør det, det går på bekostning av skiturene, humrer hun, vel vitende om at hennes manglende skiferdigheter ikke er en hemmelighet. Mat har hun derimot greie på, og snakker varmt om den røde, malte paprikaen som brukes i ungarsk mat og som gir rettene en nydelig farge. Med spesielt interesserte nevrologer har hun utvekslet oppskrifter. På hjerne.

- Ja, i Ungarn, som i enkelte andre land, er hjerne en delikatesse. Så jeg har oversatt et par oppskrifter på hvordan man tilbereder kalvehjerne. Jeg likte også godt å spise kalvehjerne helt til jeg begynte på medisinstudiet. Da jeg hadde dissekert noen, mistet jeg lysten.

- I Norge er ikke hjerne så vanlig på middagsbordet.

- Nei, men dere spiser jo lungemos!

\section{Eline Feiring}

eline.feiring@legeforeningen.no

Tidsskriftet 